\title{
BEHAVIOUR OF BALANCED LETHAL GENES OCCURRING IN PROGENY OF X-RAYED RICE')
}

\author{
YOSHIWO KATAYAMA AND SHOJIRO SHIDA
}

Faculty of Agriculture, Miyazaki University, Miyazaki 880-00

Received December 22, 1967

Balanced lethals such as found in Drosophila melanogaster by Muller (1918) are not reported so many in animals and plants. As our related examples, three such cases are known; i. e., chlorophyll mutants in oats (Nishiyama, 1934) and barley (cf. Gardner, 1960), and an incomplete endosperm variant in maize (Bianchi and Morandi, 1962).

Some years ago, several progeny strains of X-rayed rice with anomalous leaf pigmentations were kindly supplied by Dr. Y. Nishimura. Pedigree tests were done by the present authors, and a special strain which segregates greens and yellows in a ratio of $1: 1$ was detected. The yellow seedlings soon died off but the greens persistently segregated into greens and yellows in the same ratio. A provisional assumption of two recessive lethal genes was thus made (Katayama and Shida, 1963).

The following experimental procedures have been then adopted in order to examine the validity of the assumption: 1) selfing, 2) crossing with normal green strains, and 3) irradiation with $\gamma$-rays. The results obtained from the examination are described in the present paper.

\section{MATERIALS AND METHODS}

The mutant strain studied in this paper was originated from yellow variants found in 1958 in the $\mathrm{X}_{2}$ generation of X-rayed seeds of Norin No. 8, one of popular strains of Japanese rice. The yellow tint varied with environmental conditions at the time of sowing and sometimes showed faint yellow. The yellow individuals followed gradually to death after the three-leaf stage. For selfing, caution was taken to avoid outcrossing by cultivating them in an isolated plot and sometimes by bagging with paraffin paper when natural crossing was suspected.

In survey of segregation, seeds were sown in middle May, and the observation of the yellow leaf colour was made at one- and two- leaf stages, counting the numbers of the green and yellow seedlings. Good seed germinations were observed in general. This mutant was crossed with either of two normal green strains, Muketsu-to (a strain of paddy rice with a deep green colour and less tillers) or Dango-mochi No. 2 (a strain of upland rice).

Irradiation of dry seeds of this mutant strain with $\gamma$-rays from a 6,000 curie ${ }^{137} \mathrm{Cs}$

1) Contributions from the Laboratory of Plant Breeding, Faculty of Agriculture, Miyazaki University, No. 35. 
source was made at the National Institute of Genetics. The $\gamma$-ray intensity was $5 \mathrm{kR} / \mathrm{hr}$, and the exposures applied were 10,20 and 30kR. The irradiated seeds were sent immediately back to our laboratory and were sown with least delay.

\section{SEGREGATION RESULTS}

\section{(1) Selfing}

Segregation in the progeny produced by selfing was investigated from 1961 to 1966, and the results are presented in Table 1 . In the selied first generation $\left(S_{1}\right)$, a segregation ratio of greens : yellows $=1: 1$ was obtained. The same segregation ratio was also found in 34 lines of the second generation $\left(\mathrm{S}_{2}\right)$, and no constant green line was detected.

Tablể 1. Segregations in selfed progenies (1961 1966)

\begin{tabular}{|c|c|c|c|c|c|c|c|c|}
\hline Generation & $\begin{array}{l}\text { Phenotype } \\
\text { of previous } \\
\text { generation }\end{array}$ & $\begin{array}{l}\text { No. of } \\
\text { lines }\end{array}$ & $\begin{array}{c}\text { Green } \\
\text { individuals }\end{array}$ & $\begin{array}{c}\text { Yellow } \\
\text { individuals }\end{array}$ & $\begin{array}{c}\text { Total } \\
\text { number }\end{array}$ & $\begin{array}{l}\text { Assumed } \\
\text { ratio }\end{array}$ & $\chi^{2}$ & $\mathrm{P}$ \\
\hline $\mathrm{S}_{1}$ & green & 1 & 52 & 51 & 103 & $1: 1$ & 0.010 & $>0.9$ \\
\hline $\mathrm{S}_{2}$ & green & 34 & 1014 & 999 & 2013 & $1: 1$ & 0.112 & $0.8-0.7$ \\
\hline $\mathrm{S}_{3}$ & green & $\begin{array}{r}1 \\
15\end{array}$ & $\begin{array}{r}38 \\
313\end{array}$ & $\begin{array}{r}0 \\
309\end{array}$ & $\begin{array}{r}38 \\
622\end{array}$ & $1: 1$ & 0.025 & $0.9-0.8$ \\
\hline \multirow[t]{2}{*}{$\mathrm{S}_{4}$} & green & $\begin{array}{r}19 \\
1 \\
19 \\
20 \\
20\end{array}$ & $\begin{array}{r}433 \\
67 \\
716 \\
674 \\
674\end{array}$ & $\begin{array}{r}450 \\
1 \\
741 \\
630 \\
659\end{array}$ & $\begin{array}{r}883 \\
68 \\
1457 \\
1304 \\
1333\end{array}$ & $\begin{array}{l}1: 1 \\
1: 1 \\
1: 1 \\
1: 1\end{array}$ & $\begin{array}{l}0.327 \\
\\
0.429 \\
1.485 \\
0.169\end{array}$ & $\begin{array}{l}0.7-0.5 \\
0.7-0.5 \\
0.3-0.2 \\
0.7-0.5\end{array}$ \\
\hline & green* & $\begin{array}{l}19 \\
11\end{array}$ & $\begin{array}{r}1382 \\
841\end{array}$ & $\begin{array}{r}0 \\
31\end{array}$ & $\begin{array}{r}1382 \\
872\end{array}$ & & & \\
\hline \multirow[t]{2}{*}{$\mathrm{S}_{5}$} & green & $\begin{array}{l}5 \\
4 \\
5 \\
4\end{array}$ & $\begin{array}{l}136 \\
115 \\
158 \\
142\end{array}$ & $\begin{array}{l}122 \\
106 \\
152 \\
155\end{array}$ & $\begin{array}{l}258 \\
221 \\
310 \\
297\end{array}$ & $\begin{array}{l}1: 1 \\
1: 1 \\
1: 1 \\
1: 1\end{array}$ & $\begin{array}{l}0.760 \\
0.367 \\
0.116 \\
0.490\end{array}$ & $\begin{array}{l}0.5-0.3 \\
0.7-0.5 \\
0.8-0.7 \\
0.5-0.3\end{array}$ \\
\hline & green* & $\begin{array}{l}3 \\
1\end{array}$ & $\begin{array}{r}204 \\
30\end{array}$ & $\begin{array}{l}0 \\
1\end{array}$ & $\begin{array}{r}204 \\
31\end{array}$ & & & \\
\hline $\mathrm{S}_{6}$ & green & $\begin{array}{l}5 \\
5 \\
5\end{array}$ & $\begin{array}{l}179 \\
281 \\
350\end{array}$ & $\begin{array}{l}175 \\
273 \\
356\end{array}$ & $\begin{array}{l}354 \\
554 \\
706\end{array}$ & $\begin{array}{l}1: 1 \\
1: 1 \\
1: 1\end{array}$ & $\begin{array}{l}0.045 \\
0.116 \\
0.051\end{array}$ & $\begin{array}{l}0.9-0.8 \\
0.8-0.7 \\
0.9-0.8\end{array}$ \\
\hline
\end{tabular}

* Subsequent generation of constantly or predominently green lines. Others are the progeny of the $1: 1$ segregating lines.

Almost all of the $\mathrm{S}_{3}$ lines showed the $1: 1$ segregation, but one line produced only green individuals. In the subsequent selfed generation $\left(\mathrm{S}_{4}\right)$ of this green line, 19 out of 30 lines examined bred true, while the remaining 11 lines showed segregation of yellow individuals but at a low percentage (about $3.5 \%$ on the average). Out of $79 \mathrm{~S}_{4}$ lines of four groups derived from the 1: 1 segregating greens, on the other hand, 78 lines were consisted of greens and yellows in the ratio of $1: 1$, and only one line was predominantly of greens except for one yellow individual. In the next generation $\left(\mathrm{S}_{5}\right)$ 
of this predominantly green line, three out of four lines bred true whereas the remaining one contained one yellow seedling among the 31 descendants. The $1: 1$ segregation ratio was kept in the $S_{5}$ and $S_{6}$ when the parents were picked up from the inconstantly green (1: 1 segregating) $S_{4}$ lines.

Moreover, the survival greens of this mutant strain underwent a normal meiosis forming $12_{\mathbf{I}}$ at the first metaphase, and the development of the pollen grains and their germination on the stigma were also normal. A satisfactory ripening of seeds and a high seed-setting rate were observed, being comparable with those in control rice plants.

\section{(2) Test-crossings}

Segregations in the hybrid progenies between this mutant strain and Muketsu-to or Dango-mochi are presented in Table 2.

Mutant $\times$ Muketsu-to: The $\mathrm{F}_{1}$ plants had green stems and leaves. Segregations of 43 greens and 2 yellows or of 51 greens and 15 yellows were observed in the $F_{2}$. The two yellow seedlings in the former segregation had a whitish yellow colour and

Table 2. Segregations in the hybrid progenies between the mutant line and normal green rice (1964 1966)

\begin{tabular}{l|c|c|c|c|c|c|c|c}
\hline \hline Generation & $\begin{array}{c}\text { Phenotype } \\
\text { of previous } \\
\text { generation }\end{array}$ & $\begin{array}{c}\text { No. of } \\
\text { lines }\end{array}$ & $\begin{array}{c}\text { Green } \\
\text { individuals }\end{array}$ & $\begin{array}{c}\text { Yellow } \\
\text { individuals }\end{array}$ & $\begin{array}{c}\text { Total } \\
\text { number }\end{array}$ & $\begin{array}{c}\text { Assumed } \\
\text { ratio }\end{array}$ & $\chi^{2}$ & $\mathrm{P}$ \\
\hline
\end{tabular}

(1) Mutant $\times$ Muketsu-to

\begin{tabular}{|c|c|c|c|c|c|c|c|c|}
\hline $\mathrm{F}_{2}$ & green & $\begin{array}{l}1 \\
1\end{array}$ & $\begin{array}{l}43 \\
51\end{array}$ & $\begin{array}{r}2 \\
15\end{array}$ & $\begin{array}{l}45 \\
66\end{array}$ & $3:$ & 0.181 & $0.7-0.5$ \\
\hline $\mathrm{F}_{3}$ & green* & $\begin{array}{l}5 \\
1 \\
4 \\
3 \\
2\end{array}$ & $\begin{array}{r}297 \\
53 \\
210 \\
180 \\
66\end{array}$ & $\begin{array}{r}0 \\
1 \\
31 \\
53 \\
58\end{array}$ & $\begin{array}{r}295 \\
54 \\
241 \\
233 \\
124\end{array}$ & $\begin{array}{l}3: \\
1:\end{array}$ & $\begin{array}{l}0.631 \\
0.516\end{array}$ & $\begin{array}{l}0.5-0.3 \\
0.5-0.3\end{array}$ \\
\hline \multirow[t]{2}{*}{$\mathrm{F}_{4}$} & green* & $\begin{array}{l}2 \\
2 \\
2\end{array}$ & $\begin{array}{l}165 \\
145 \\
115\end{array}$ & $\begin{array}{r}0 \\
22 \\
31\end{array}$ & $\begin{array}{l}165 \\
167 \\
146\end{array}$ & $3:$ & 1.105 & $0.3-0.2$ \\
\hline & green** & 6 & 181 & 171 & 352 & $1:$ & 0.284 & $0.7-0.5$ \\
\hline
\end{tabular}

(2) Mutant $\times$ Dango-mochi

\begin{tabular}{|c|c|c|c|c|c|c|c|c|}
\hline $\mathrm{F}_{2}$ & green & $\begin{array}{l}1 \\
1\end{array}$ & $\begin{array}{l}79 \\
43\end{array}$ & $\begin{array}{r}2 \\
11\end{array}$ & $\begin{array}{l}81 \\
54\end{array}$ & $3: 1$ & 0.617 & $0.5-0.3$ \\
\hline $\mathrm{F}_{3}$ & green* & $\begin{array}{l}3 \\
4 \\
5 \\
3\end{array}$ & $\begin{array}{l}214 \\
280 \\
254 \\
113\end{array}$ & $\begin{array}{r}0 \\
54 \\
86 \\
105\end{array}$ & $\begin{array}{l}214 \\
334 \\
340 \\
218\end{array}$ & 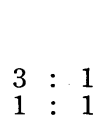 & $\begin{array}{l}0.016 \\
0.293\end{array}$ & $\begin{array}{l}0.9-0.8 \\
0.7-0.5\end{array}$ \\
\hline \multirow[t]{2}{*}{$\mathrm{F}_{4}$} & green* & $\begin{array}{l}2 \\
2 \\
1 \\
1\end{array}$ & $\begin{array}{r}138 \\
157 \\
44 \\
42\end{array}$ & $\begin{array}{r}0 \\
12 \\
25 \\
42\end{array}$ & $\begin{array}{r}138 \\
169 \\
69 \\
84\end{array}$ & $1: 1$ & 0 & 1 \\
\hline & green** & 6 & 183 & 197 & 380 & $1: 1$ & 0.516 & $0.5-0.3$ \\
\hline
\end{tabular}

* Previous generation showed $3: 1$ segregation.

** Previous generation showed $1: 1$ segregation. 
the segregation could not be regarded as a simple recessive ratio. But the yellow individuals in the latter segregation were somewhat greenish in colour and the segregation could be fitted to the $3: 1$ ratio. In the $F_{3}$ of the latter line various segregation ratios were observed. Namely, out of $15 \mathrm{~F}_{3}$ lines examined, five bred true as greens; one contained only one yellow individual ; four were consisted of more greens and less yellows than expected from the $3: 1$ ratio; three were of segregations close to a $3: 1$ ratio; and the remaining two lines approximated a $1: 1$ ratio.

When the $\mathrm{F}_{4}$ lines were taken from the green plants of the $\mathrm{F}_{3}$ lines which showed the $3: 1$ segregation, the following three different segregations were observed: All greens (two lines); more greens and less yellows than the $3: 1$ ratio (two lines); and greens and yellows in the $3: 1$ ratio (two lines). When the $F_{4}$ lines were derived from the $1: 1$ segregating $F_{3}$ lines, on the other hand, segregations of greens and yellows close to a $1: 1$ ratio were observed in all of the six $\mathrm{F}_{4}$ lines.

Mutant $\times$ Dango-mochi : The $\mathrm{F}_{1}$ hybrids also had a normal green colour. The segregations in the $F_{2}$ and the subsequent generations were similar to those observed in the above mentioned combination. That is, one group of the $F_{2}$ contained only two yellows among 81 plants, while the other did 43 greens and 11 yellows. The former yellows were whitish and of very low percentage. The latter ysllows were somewhat greenish and fitted to a $3: 1$ ratio. This $3: 1$ segregating line showed various segregation types in the $\mathrm{F}_{3}$ generation. Out of $15 \mathrm{~F}_{3}$ lines investigated, three lines contained no yellow seedling; four lines with less yellows than $25 \%$; five lines approximately $25 \%$ yellows $(3: 1)$; and three lines $50 \%(1: 1)$.

The $\mathrm{F}_{4}$ generation was taken from the $3: 1$ and $1: 1$ segregating $\mathrm{F}_{3}$ lines. Six $\mathrm{F}_{4}$ lines from the former segregating type showed the following four different segregations: All greens (two lines); more greens and less yellows than the $3: 1$ ratio (two lines); greens and yellows in an intermediate ratio between $3: 1$ and $1: 1$ (one line); and the both in the $1: 1$ ratio (one line). On the other hand, all the six $F_{4}$ lines from the $1: 1$ segregating type showed the same 1:1 segregation.

\section{(3) $\gamma$-ray treatments}

The mutant strain was irradiated with $\gamma$-rays and the progenies $\left(R_{2}-R_{4}\right)$ were investigated. In the $R_{2}$ segregation three new strains appeared in which found were segregations of three types, i.e., green, yellow and faint yellow. In their subsequent generations, progeny test was made and the results are summarized in Table 3 (cf. Katayama and Shida, 1967).

No. 4019 strain: In the $\mathrm{R}_{2}$ generation from seeds exposed to $20 \mathrm{kR}$ of $\gamma$-rays, the segregation in three phenotypes, green, yellow and faint yellow, was $16: 14: 9$ which is close to a $3: 3: 2$ ratio. The most of the yellow and faint yellow individuals died after the three-leaf stage. Five $R_{3}$ lines examined contained the three phenotypes in the $3: 3: 2$ ratio. In the $R_{4}$, however, three lines consisting only with greens and yellows in an approximate $1: 1$ ratio but not with plants of faint yellow were found. In other three lines of the $\mathrm{R}_{4}$ generation, the $3: 3: 2$ segregation was observed.

No. 4023 strain: In the $\mathrm{R}_{2}$ of seeds exposed to $30 \mathrm{kR}$ of $\gamma$-rays, three phenotypes were found in a ratio of $14: 29: 13$. In the $R_{3}$, two types of segregations were observed 
Table 3. Segregations in three identical mutant strains newly obtained by $\gamma$-ray treatments

\begin{tabular}{|c|c|c|c|c|c|c|c|c|c|}
\hline Generation & $\begin{array}{l}\text { Phenotype } \\
\text { of previous } \\
\text { generation }\end{array}$ & $\begin{array}{l}\text { No. of } \\
\text { lines }\end{array}$ & $\begin{array}{c}\text { Green } \\
\text { individuals }\end{array}$ & $\begin{array}{c}\text { Yellow } \\
\text { individuals }\end{array}$ & $\begin{array}{c}\text { Faint } \\
\text { yellow } \\
\text { individuals }\end{array}$ & $\begin{array}{c}\text { Total } \\
\text { number }\end{array}$ & $\underset{\text { ratio }}{\text { Assumed }}$ & $\chi^{2}$ & $\mathrm{P}$ \\
\hline
\end{tabular}

(1) No. $4019(1964 \sim 1966)$

\begin{tabular}{|c|c|c|c|c|c|c|c|c|c|}
\hline $\mathrm{R}_{2}$ & green & 1 & 16 & 14 & 9 & 39 & $3: 3: 2$ & 0.129 & $>0.9$ \\
\hline $\mathrm{R}_{3}$ & green* & 5 & 129 & 123 & 77 & 329 & $3: 3: 2$ & 0.592 & $0.8-0.7$ \\
\hline $\mathrm{R}_{4}$ & green* & $\begin{array}{l}3 \\
3\end{array}$ & $\begin{array}{l}80 \\
97\end{array}$ & $\begin{array}{r}66 \\
108\end{array}$ & $\begin{array}{r}0 \\
63\end{array}$ & $\begin{array}{l}146 \\
268\end{array}$ & $\begin{array}{l}1: 1 \\
3: 3: 2\end{array}$ & $\begin{array}{l}1.342 \\
0.920\end{array}$ & $\begin{array}{l}0.3-0.2 \\
0.7-0.5\end{array}$ \\
\hline
\end{tabular}

(2) No. $4023(1964 \sim 1965)$

\begin{tabular}{|c|c|c|c|c|c|c|c|c|c|}
\hline $\mathrm{R}_{2}$ & green & 1 & 14 & 29 & 13 & 56 & $3: 3: 2$ & 5.452 & $0.1-0.05$ \\
\hline $\mathrm{R}_{3}$ & green* & $\begin{array}{l}3 \\
7\end{array}$ & $\begin{array}{r}50 \\
115\end{array}$ & $\begin{array}{r}51 \\
137\end{array}$ & $\begin{array}{r}0 \\
100\end{array}$ & $\begin{array}{l}101 \\
352\end{array}$ & $\begin{array}{l}1: 1 \\
3: 3: 2\end{array}$ & $\begin{array}{l}0.005 \\
4.015\end{array}$ & $\begin{array}{r}>0.9 \\
0.2-0.1\end{array}$ \\
\hline
\end{tabular}

(3) No. 4025 (1964 1966)

\begin{tabular}{|c|c|c|c|c|c|c|c|c|c|}
\hline $\mathrm{R}_{2}$ & green & 1 & 14 & 27 & 4 & 45 & $3: 3: 2$ & 11.237 & $0.01-0.001$ \\
\hline $\mathrm{R}_{3}$ & green* & $\begin{array}{l}2 \\
4\end{array}$ & $\begin{array}{l}57 \\
65\end{array}$ & $\begin{array}{l}65 \\
71\end{array}$ & $\begin{array}{r}0 \\
44\end{array}$ & $\begin{array}{l}122 \\
180\end{array}$ & $\begin{array}{l}1: 1 \\
3: 3: 2\end{array}$ & $\begin{array}{l}0.525 \\
0.296\end{array}$ & $\begin{array}{l}0.5-0.3 \\
0.9-0.8\end{array}$ \\
\hline $\mathrm{R}_{4}$ & green* & $\begin{array}{l}2 \\
4\end{array}$ & $\begin{array}{r}71 \\
104\end{array}$ & $\begin{array}{r}81 \\
112\end{array}$ & $\begin{array}{r}0 \\
63\end{array}$ & $\begin{array}{l}152 \\
279\end{array}$ & $\begin{array}{l}1: 1 \\
3: 3: 2\end{array}$ & $\begin{array}{l}0.658 \\
1.177\end{array}$ & $\begin{array}{l}0.5-0.3 \\
0.7-0.5\end{array}$ \\
\hline
\end{tabular}

* The next generation of the $3: 3: 2$ segregating lines.

as in the $\mathrm{R}_{4}$ of the strain No. 4019 ( $1: 1$ and roughly $3: 3: 2$ ).

No. 4025 strain: In the $\mathrm{R}_{2}$ of another $30 \mathrm{kR}$-irradiated experiment, the three phenotypes also appeared but in a ratio which does not fit to the $3: 3: 2$. However, among six $R_{3}$ lines tested, two and four lines were found to be classifiable to the $1: 1$ and $3: 3: 2$ segregating types, respectively. Segregations observed in the $R_{4}$ lines derived from the $3: 3: 2$ segregating $R_{3}$ were similar to those in the $R_{3}$.

These three newly obtained mutant strains may be regarded as the results of an identical mutation induced by $\gamma$-rays, because of the above almost identical genetic behaviour they showed.

\section{DISCUSSION}

In order to account for the heredity of a chlorophyll variant which occurred in the progeny of X-rayed rice and habitually segregated greens and yellows in a ratio of $1: 1$ (the yellows die soon, i.e., they are lethal), the present authors (Katayama and Shida, 1963) made a tentative assumption of balanced lethal genes as proposed by Muller (1918). Further investigations have proved the validity of the assumption, thus conclusive explanations are offered here.

Now suppose $l_{1}$ and $l_{2}$ as two recessive lethal genes induced by the earlier X-ray treatment, which are unable to undergo normal chlorophyll formation, and $L_{1}$ and $L_{2}$ as the respective normal dominant alleles. Existence of both the $L_{1}$ and $L_{2}$ results in 
normal green, but when either of the loci is homozygous for the recessive genes (i.e., $l_{1} l_{1}$ or $l_{2} l_{2}$ ) the yellow colour sppears and plants become lethal. Further suppose that $L_{1}$ gene is located very close to $l_{2}$ gene, and the same situation for $l_{1}$ and $L_{2}$ genes. That is, two sets of two complementary genes $\left(L_{1}\right.$ plus $l_{2}$ and $l_{1}$ plus $L_{2}$ ) located very close to each other are carried by a set of homologous chromosomes. A green plant of this mutant strain has $L_{1}$ and $l_{2}$ on one of the homologous chromosomes (designated here as $\overline{\left.L_{1} l_{2}\right)}$ and $l_{1}$ and $L_{2}$ on the other $\overline{\left(l_{1} L_{2}\right)}$. Recombination between $L$ and $l$ genes is supposed to occur scarcely. Selfing of the greens brings about $\overline{L_{1} l_{2}} \overline{L_{1} l_{2}}, \overline{L_{1} l_{2}} \overline{l_{1} L_{2}}$ and $\overline{l_{1} L_{2}} \overline{l_{1} L_{2}}$ in a ratio of $1: 2: 1$, and the two homozygous types, either for $l_{1}$ or $l_{2}$ gene, are yellow and lethal, and the heterozygous type green. Consequently this line segregates habitually greens and yellows in the $1: 1$ ratio as described above. Rare ocurrence of constant green lines may be explained by mutable recurrence from $l_{1}$ and $l_{2}$ to $L_{1}$ and $L_{2}$ respectively. Stress should be laid on significance of the heredity due to balanced lethal genes as a mechanism which protects permanent heterozygosity (cf. Sinnot et al. 1950). This slso relates to the problem of heterosis breeding.

The $F_{1}$ hybrids between this mutant strain and normal green rice were green, and the $\mathrm{F}_{2}$ showed two different segregations of greens and yellows, i.e., a $3: 1$ and a predominantly green-producing segregations. The yellows in the former segregation were somewhat greenish and those in the latter were whitish in colour ${ }^{1}$. This may be explained at least partly as follows. Since the gene component of the original mutant is $\bar{L}_{1} l_{2} \bar{l}_{1} L_{2}$, the $\mathrm{F}_{1}$ hybrids must have either of the components, $\overline{L_{1} l_{2}} \overline{L_{1} L_{2}}$ or $\overline{l_{1} L_{2}} \overline{L_{1} L_{2}}$. Thus, if there is no competitive fertilization between pollens with different genotypes, only the $3: 1$ segregation is expected in the $F_{2}$. However, if a competition between the double dominant pollen and the lethal-gene-carrying pollen occurs, being the former pollen surpassing over the latter in fertilization, green $F_{2}$ individuals must be increased. As the segregation of the yellows at a low percentage was observed in the present study, it may be assumed that such a competitive fertilization between pollen grains with different genotypes had occurred (cf. Nishiyama, 1936). Although it is uncertain which of the $\overline{L_{1} l_{2}}$ and $\overline{l_{1} L_{2}}$ pollens is inferior to $\overline{L_{1} L_{2}}$ pollen, it may be assumed provisionally that the $\overline{l_{1} L_{2}}$ pollen (brings whitish seedling) is inferior to the $\overline{L_{1} L_{2}}$ pollen but the $\overline{L_{1} l_{2}}$ pollen (brings greenish seedling) is not. With this assumption, the $\bar{l}_{1} L_{2} \overline{L_{1} L_{2}} F_{1}$ produces more greens and less yellows than the $3: 1$ ratio in the $\mathrm{F}_{2}$, while the $\overline{L_{1} l_{2}} \overline{L_{1} L_{2}}$ $F_{1}$ gives the both in the $3: 1$ ratio in the next generation. However, some types of anomalous segregations observed in the $F_{3}$ or $F_{4}$ derived from the $3: 1$ segregating $F_{2}$ or $\mathrm{F}_{3}$ can not be explained only by this assumption (see Table 2). Namely, a mutational change of $L_{1}$ to $l_{1}$ is necessary to produce the $1: 1$ segregating lines, and changes of $L_{1}$ to $l_{1}$ and of $l_{2}$ to $L_{2}$ are necessary to result in the green-predominant segregation. Also, it is necessary to consider that these changes must have occurred at high frequencies. At any rate, the research conducted so far does not supply sufficient data to discuss more on these points.

In the progeny of $\gamma$-rayed original mutant strain, a new mutant strain which showed

1) This relation in yellows of which show whitish or greenish perhaps will be seen in the progeny of selfing, but the present investigations for distinction were not enough. 
a segregation ratio of greens : yellows : faint yellows $=3: 3: 2$ was found. The occurrence of this new mutant may be explicable by considering a $\gamma$-ray-induced recessive mutation at a locus ( $A$ to $a$ ) which is independent of above $L_{1}$ and $L_{2}$ loci but is concerned in chlorophyll formation, and by assuming that this gene behaves hypostatistically to the balanced lethal genes.

\section{SUMMARY}

1. In this paper the authors dealt with the heredity of a chlorophyll variant found in the progeny of X-rayed rice, which segregates habitually green and yellow seedlings at a ratio of $1: 1$, the yellows of which die soon. The genetic behaviour had already been explained by assuming two recessive lethal genes. Further survey of the selfed progeny was carried out as well as the examination of the mutant strain by testcrossing with other normal green rice and by $\gamma$-ray treatments.

2. Assumed were two recessive lethal genes, $l_{1}$ and $l_{2}$, which are unable to undergo normal chlorophyll formation, and the respective normal genes, $L_{1}$ and $L_{2}$. Coexistence of $L_{1}$ and $L_{2}$ produces normal greens, and loss of either of the dominant genes results in yellows. Also, both the loci are so closely linked to each other that recombination occurs scarcely between the loci, and $L_{1}$ and $l_{2}$ or $l_{1}$ and $L_{2}$ are locatcd on the same chromosome. That is, the green plants of the mutant strain has $\overline{L_{1} l_{2}} \overline{l_{1} L_{2}}$ gene component, and the selfing gives $\overline{L_{1} l_{2}} \overline{L_{1} l_{2}}: \overline{L_{1} l_{2}} \overline{l_{1} L_{2}}: \overline{l_{1} L_{2}} \overline{l_{1} L_{2}}$ in a ratio of $1: 2: 1$, the two homozygous types either for $l_{1}$ or $l_{2}$ gene being yellow and the heterozygote green.

3. Rare occurrence of constant green line in this mutant strain seems to have been caused by mutable recurrence from $l_{1}$ and $l_{2}$ to $L_{1}$ and $L_{2}$ respectively. And it is proposed that the heredity due to such balanced lethal genes has a significance as a mechanism which protects permanent heterozygosity, having a relation to heterosis breeding.

4. The $F_{1}$ hybrids between this mutant strain and normal green rice were green, and the $\mathrm{F}_{2}$ showed two different segregations; i.e., the one with 3 greens : 1 somewhat greenish yellows, and the other with predominant greens : a few whitish yellows.

5. The latter segregation may be explicable by a competitive fertilization. Since the gene components of the $\mathrm{F}_{1}$ plants are $\overline{L_{1} l_{2}} \overline{L_{1} L_{2}}$ or $\overline{l_{1} L_{2}} \overline{L_{1} L_{2}}$, if no competition occurred between the pollens with different components, a $3: 1$ segregation would be expected, while if the pollens underwent a competition, a distorted ratio would result. However, some inexplicable problems still remain to be solved.

6. Gamma-ray treatments of this mutant strain induced a new mutant strain which showed a segregation of greens, yellows and faint yellows in a ratio of $3: 3: 2$. An explanation that a recessive mutation ( $A$ to $a$ ) was newly induced may be given. This locus is considered to be independent of above $L_{1}$ and $L_{2}$ loci but to be concerned in chlorophyll formation, and this gene seems to behave hypostatically to the balanced lethal genes. 


\section{ACKNOWLEDGEMENTS}

For giving several progeny strains of X-rayed rice with anomalous leaf pigmentations, the present authors wish to express sincere thanks to Dr. Y. Nishimura who was then a technical officiail of the National Institute of Agriculture and is now a proffessor of Niigata University. And the maniplation of $\gamma$-ray irradition was taken by the late Dr. S. Matsumura and Dr. T. Fujii of the National Institute of Genetics to whom the author's profound thanks are due.

\section{LITERATURE CITED}

Bianchi, A., and A. Morandi, 1962 A case of balanced lethal factors in maize. Heredity 17: 409-414. Gardner, E. J., 1960 Principle of genetics. Jhon Wiley \& Sons, Inc. New York. pp. 231-233.

Katayama, Y., and S. Shida, 1963 Studies on the contamination and the variation of crop plants caused by radioactivity III. Anomalous lines of leaf pigment occurring in X-rayed rice progeny. Bull. Fac. Agr., Miyazaki Univ. 8: 332-339.

Katayama, Y., and S. Shida, 1967 Studies on the contamination and the variation of crop plants caused by radioactivity IV. Leaf pigment variants found in $\gamma$-rayed rice and barley progenies. Bull. Fac. Agr., Miyazaki Univ. 14: 369-376.

Muller, H. J., 1918 Genetic variability, twin hybrids, and constant hybrids in a case of balanced lethal factors. Genetics 3: 422-499.

Nishiyama, I., 1934 The genetics and cytology of certain cereals VI. Chromosome behavior and its bearing on inheritance in triploid Avena hybrids. Mem. Coll. Agr., Kyoto Imp. Univ., No. 32: $1-157$.

Nishiyama, I., 1936 Balanced lethals in Avena (A preliminary note). (In Japanese). Japan. J. Genetics 12: $41-42$.

Sinnott, E.W., L.C. Dunn, and Th. Dobzhansky, 1950 Principles of genetics. McGraw-Hill Book Company, Inc. New York. 4th Ed. pp. 271-332. 